\title{
Transcriptional Evaluation of Antioxidant and Anti-Inflammatory Potential of Buchholzia coriacea in Acetaminophen-Induced Sub-Chronic Renal and Hepatic Toxicity
}

\author{
Fakoya A, and Olusola AO* \\ Department of Biochemistry, Faculty of Sciences, Adekunle Ajasin University, Ondo State, Nigeria
}

*Corresponding author: Olusola AO, Department of Biochemistry, Faculty of Sciences, Adekunle Ajasin University, Ondo State, Nigeria, Tel: 8035129957; E-mail: austinolusola@gmail.com

Received: 01 Sep, 2020 | Accepted: 16 Oct, 2020 | Published: 23 Oct, 2020

Citation: Fakoya A, Olusola AO (2020) Transcriptional Evaluation of Antioxidant and Anti-Inflammatory Potential of Buchholzia coriacea in Acetaminophen-Induced Sub-Chronic Renal and Hepatic Toxicity. J Biochem Analyt Stud 4(3): dx.doi.org/10.16966/2576-5833.124

Copyright: (C) 2020 Fakoya A, et al. This is an open-access article distributed under the terms of the Creative Commons Attribution License, which permits unrestricted use, distribution, and reproduction in any medium, provided the original author and source are credited.

\begin{abstract}
The aim of this research was to evaluate the possible renal and Hepato-protective effects of ethanolic extract of Buchholzia coriacea seed compared to $\mathrm{N}$-acetylcysteine, on gene expression in the liver and kidneys of Wistar rats subjected to sub-chronic dose of paracetamol. Forty wistar rats were divided into eight groups of five rats in each group. Group 1 received only normal diet as control (CTRL). Groups $2-6$ received $14.28 \mathrm{mg} / \mathrm{kg}$ body weight of Paracetamol (PM). After 6 hours, $200 \mathrm{mg} / \mathrm{kg}$ body weight of extract (E1) was given to group 3, $400 \mathrm{mg} / \mathrm{kg}$ body weight extracts (E2) given to group 4,70 and $150 \mathrm{mg} / \mathrm{kg}$ body weight of $\mathrm{N}$-acetylcysteine was administered to group 5 and 6 respectively. Groups 7 and 8 received only 200 and $400 \mathrm{mg} / \mathrm{kg}$ body weight of extract (E1 and E2) respectively. This schedule was maintained for 90 days.

The animals were sacrificed; liver and kidneys were excised for gene expression analysis. Our results showed that administration of Buchholzia coriacea extract down-regulated the expression of fas ligand, KIM-1, interlukin-6 and prostaglandin in the kidneys relative to control (Group 1). Pre-treatment with acetaminophen followed by Buchholzia coriacea extract in the liver down-regulated the expression of GST, GPX-1 and CYP1A2 compared to the control (Group 1). While administration of Buchholzia coriacea extract up-regulated the expression of GST, GPX-1 and CYP1A2 genes in the liver. Also, significant increase $(p<0.033)$ in GST expression was seen in E1 group when compared to PM group. Decreased level of GPX-1 was seen in PM treated group when compared to control group. However, an increased level was seen in groups treated with PM+E1 when compared to PM treated and control groups. In conclusion, the ethanolic extract of Buchhozia coriacea seeds exhibited high antioxidant and antiinflammatory properties through which it could reduce apoptosis and detoxify harmful substances in the liver and kidney. These activities could be interpreted as renal and hepatoprotective. Therefore, the extract from Buchholzia coriacea seeds could be proposed as an antidote in the treatment of acetaminophen toxicity.
\end{abstract}

Keywords: Detoxification; Expression of gene; Renal and hepatoprotective; N-acetylcysteine; Paracetamol toxicity

\section{Introduction}

Acetaminophen, also known as paracetamol, is a medicine used to treat mild to moderate pains. In combination with opioid anti-pain medication, paracetamol is also used for severe conditions such as cancer and after surgery pains [1]. It can also be used in the treatment of lower back pain; headache and teeth ache [2]. Paracetamol does not have significant anti-inflammatory effects [3]. It is sometimes used as the first-line treatment for pain and pyrexia, it plays an important role in multimodal analgesia [4] and it is considered to possess a generally excellent safety profile except in significant overdose, with few drug interactions. Its effects last between 2 and 4 hours [2]. The recommended maximum daily dose for an adult is 3 or 4 grams [5]. High doses may cause hepatic toxicity.
$\mathrm{N}$-acetyl cysteine (NAC), a thiol containing amino acid, has been in clinical use for over 30 years, primarily as an antidote for acetaminophen overdose [6,7]. NAC is a precursor in the Glutathione (GSH) synthesis pathway and NAC's potential protective function has been linked to prevention of chronic diseases characterized by decreased GSH and/or increased oxidative stress such as alcoholic liver disease [8,7]. Being a source of sulfhydryl groups, NAC supports Glutathione-S-transferase (GST) activity, an important phase II detoxification enzyme. In addition, NAC is believed to promote detoxification and to act as a scavenger of free radicals due to its direct interaction with ROS $[9,7]$. NAC is a drug designed for protection against a single high dose of paracetamol and there is little evidence to guide risk assessment and optimal treatment for over-exposures, chronic exposures or repeated supra-therapeutic exposures [10,11]. 
The liver, an essential organ, performs vital functions within the human body and is composed of numerous cell types. It is a multifunctional and highly regenerative organ. The major metabolic cell type of the liver, the hepatocyte, is susceptible to damage during drug overdose. In both the acute and chronic phases, liver damage has dire consequences for health. Liver damage is caused by adverse reactions to drugs, which can lead to Drug Induced Liver Injury (DILI). This creates major problems for patients, clinicians, the pharmaceutical industry and regulatory authorities [12]. Liver injury caused by acetaminophen overdose is the leading cause of Acute Liver Failure (ALF) in the western world, and this accounts for nearly half of all of the ALF cases $[13,14]$. CYP450 enzymes in liver, specifically isoforms such as CYP2E1, CYP3A4 and CYP1A2, metabolize acetaminophen to $\mathrm{N}$-acetyl-p-benzoquinoneimine (NAPQI), a hepatotoxic metabolite [15]. NAPQI binds to cellular proteins, specifically mitochondrial proteins, and triggers an intracellular signalling cascade ultimately resulting in liver necrosis [16-18], revealed that 2,3,4,5-tetrahydroxystilbene-2-O- $\beta$-D-glucoside (TSG) is the main active compound in Polygonum multiforum Thunb. This plant has various pharmacological activities such as anti-infammatory, anti-aging, hypolipidemic, hypotensive, cardio-protective and neuroprotective effects $[19,18]$. Liver mRNA expression of CYP1A2 was increased in mice treated with different doses of TSG $(100,200$, $400,800 \mathrm{mg} / \mathrm{kg}$ ) for $12 \mathrm{hrs}$. It was found that TSG exacerbated acetaminophen-induced liver injury at the first time. Furthermore, the study showed that TSG augmented acetaminophen-induced liver injury by increasing the expression and catalytic activation of liver CYP1A2. TSG was seen to increase the expression of CYP1A2 in mice and in human normal liver and thus exacerbates the hepatotoxicity. It was further shown by Xu S, et al. [18] that Aryl Hydrocarbon Receptor (AHR) and Pregnane X Receptor (PXR) are responsible for up- regulating the transcriptional expression and activity of hepatic CYP1A2 in mice. AHR or PXR inhibitors were found to reduce the expression and activity of hepatic CYP1A2 and CYP3A4 in mice. According to Jóźwiak-Bebenista and Nowak [20], acetaminophen is a weak COX-2 inhibitor. A result obtained by Soliman MM, et al. [21] also showed that curcumin modulates the inflammatory response by down-regulating the activity of cyclooxygenase- 2 in acute liver injury induced by acetaminophen. In a research conducted by Jurenka JS [22], curcumin modulated the inflammatory response by downregulating the activity of COX-2. This shows that curcumin is an antiinflammatory substance $[22,23]$.

The nephron is the basic structural and functional unit of the kidney, which filters the blood in order to regulate reabsorption and excretion of waste products, and thereby produces urine [24]. Toxic chemicals and medications may cause nephro-toxicity [25]. The nephrotoxic effect of most drugs is more profound in patients already suffering from kidney impairment. A decreased creatinine clearance indicates poor renal function, which may be more useful clinically when assessing patients for early kidney disease.

Buchholzia coriacea (Wonderful kola) is an evergreen shrub belonging to the family Capparidaceae [26]. It is found in many tropical countries like Ghana, Gabon, Cameroon, Central African Republic, Congo, Angola, Nigeria, among others [27]. The ethanolic extract of Buchholzia coriacea Engler seed was revealed to have antitrypanosomal activity in mice experimentally infected with Trypanosoma brucei $[28,26]$. It was also discovered that the plant possessed antiplasmodial [29], antibacterial $[30,26]$, larvicidal effect [31], antiplasmodial and anti-diarrhetic [32], analgesic [33] and anthelminthic $[34,31]$ properties.
Previous studies by Anowi and colleagues [32], showed that ethanolic extract of Buchholzia coriacea elicited hypoglycemic effect that exhibited synergistic action with the hypoglycemic agent, metformin. Also, a study was conducted to investigate the phytochemical constituents and antibacterial activity of leaf extracts of wonderful kola on pathogenic Staphylococcus aureus strains. Using agar well diffusion method, antibacterial activity of Buchholzia coriacea extract was evaluated to determine the zones of inhibition and Minimum Inhibitory Concentration (MIC) [35]. Phytochemical analysis revealed that the leaf of Buchholzia coriacea contained phylobatannins, carbohydrates, proteins, tannins, saponins, alkaloids and flavonoids. Varying zones of inhibition was produced by the ethanolic extract (10-14 $\mathrm{mm})$ and methanolic extracts $(13-15 \mathrm{~mm})$ against the $S$. aureus strains. This revealed that the extract of the leaves of Buchholzia coriacea plant can inhibit pathogenic strains of $S$. aureus [35].

Recently, evidence has shown that there is a gradual revival of interest in the use of medicinal plants, because of its safety and less side effect especially when compared with synthetic drugs [36]. This study is designed to evaluate the geno-modulatory effect of Buchholzia coriacea seeds in the administration of recommended dose of paracetamol for three months and assess the effects of sub-chronic dose of paracetamol administration in liver and kidney.

\section{Materials and Methods}

\section{Equipment and laboratory apparatus}

Polymerase Chain Reaction (PCR) machine (Multi-gene optimax), thermocycler machine, (Multigene Optimax, USA), refrigerator, Eppendorf tube, desiccator, table centrifuge (Biofuge, Germany), spectrophotometer (JENWAY, UK), gel electrophoresis machine (USA), micropipette, photophoresis (USA).

\section{Chemicals and reagents}

$\mathrm{N}$-acetyl cysteine, ethidium bromide, tracking dye, iso-propyl ethanol, acetaminophen (GSK paracetamol), master mix (Biolabs, New England), RNA snap kits (lysis solution), tris-borate EDTA (Biolabs New England), agarose gel powder (Cleaver Scientific LTD, England), primers (Inqada Biotechnical Industries (Pty) LTD., South Africa), nuclease-free water (Life Sciences advanced technologies, England), reverse transcriptase (Biolabs New England), random primer (Biolabs New England), dNTPs (Biolabs New England). All chemicals and reagents used are of high analytical grade.

\section{Collection of plant materials}

The seeds of Buchholzia coriacea were bought from Oja Oba Market at Ikare Akoko, Ondo State.

\section{Identification of sample}

The seed was identified and authenticated with designated vouchernumber 025 as that of Buchholzia coriacea Engler tree plant in the Department of Plant Science and Biotechnology, Adekunle Ajasin University, Akungba Akoko (AAUA), Ondo State, Nigeria and a voucher sample has been deposited in the Herbarium of the University.

\section{Preparation of sample}

Fresh seeds of $B$. coriacea were washed with water. The washed seeds were carefully sliced. The sliced seeds were air-dried at room temperature for some weeks and then pulverized. 


\section{Extraction procedure}

Five hundred grammes of the clean, air dried and pulverized plant sample was weighed into extraction jar and $1400 \mathrm{ml}$ of analytical grade ethanol was added to the jar containing Buchholzia coriacea. The extraction mixture was given periodic constant agitation and left for 72 hours. The supernatant was decanted and concentrated using rotary evaporator at $40^{\circ} \mathrm{C}$ and the extract was freeze-dried. The extract was packed inside an air tight sample bottle and kept at $4^{\circ} \mathrm{C}$ inside the refrigerator until when needed.

\section{Animals}

Forty (40) normal male Wistar rats were purchased from the University of Ibadan, Oyo State and they were acclimatized in favorable environment for four weeks. The animals were maintained and used in accordance with the guidelines of the Committee on Care and Use of Experimental Animal Resources, Faculty of Science, Adekunle Ajasin University, Akungba Akoko, Ondo State, Nigeria.

\section{Experimental design}

Forty male Wistar rats were used for this study. The animals were randomly divided into eight groups, with five rats in each group. After acclimatization, Group 1 received only normal diet as control (CTRL). Groups 2-6 received $14.28 \mathrm{mg} / \mathrm{kg}$ body weight of Paracetamol (PM). After 6 hours, $200 \mathrm{mg} / \mathrm{kg}$ body weight of extract (E1) was given to group 3, $400 \mathrm{mg} / \mathrm{kg}$ body weight extracts (E2) given to group 4, 70 and $150 \mathrm{mg} / \mathrm{kg}$ body weight of $\mathrm{N}$-acetylcysteine was administered to group 5 and 6 respectively. Groups 7 and 8 received only 200 and $400 \mathrm{mg} /$ $\mathrm{kg}$ body weight of extract (E1 and E2) respectively. This schedule was maintained for 90 days.

\section{Animal sacrifice And Tissue excision}

At the end of the 90 days period of treatment, animals were fasted overnight and then sacrificed. Kidneys and liver tissue samples were excised into Eppendorf tubes containing $100 \mu \mathrm{l}$ RNA snap kit reagent. Tissues were homogenized and supernatants stored in the refrigerator $-4^{\circ} \mathrm{C}$.

\section{Gene expression protocol}

Semi-quantitative polymerase chain reaction protocol was used to determine the relative gene expression of the following: GST, GPX-1, COX-1, IL-6, KIM-1, prostaglandin synthase, Fas ligand with slight modifications [37].

\section{Gene expression analyses}

Total tissue RNA was extracted using TRIzol (Invitrogen) according to the manufacturer's protocol. RNA pellets were resuspended in diethyl/pyrocarbonate-treated deionized water. RNA samples were analyzed by agarose gel electrophoresis and integrity was confirmed by visualization of intact $18 \mathrm{~S}$ and $28 \mathrm{~S}$ rRNA under UV light. Spectrophotometric study (NanoDrop, Thermo Scientific 2000c) was used to confirm the purity of total RNA and then its concentration was determined. The 1-2 $\mu \mathrm{g}$ RNA was reverse-transcribed to cDNA at $42^{\circ} \mathrm{C}$ for 60 minutes. After enzyme inactivation $\left(95^{\circ} \mathrm{C}, 10\right.$ minutes), cDNA fragments were amplified for 35 cycles using gene-specific primers for the genes of interest. PCR products were resolved on $2 \%$ agarose gels and visualized using Uvitec gel documentation systems (Uvitec ArminTeb, Iran). Gene expression study was carried out by statistical analysis using Uvitec Fire Reader Software (Cambridge) to compare the groups.

\section{Results}

Gene expression results of liver pre-treated with sub-chronic dose of acetaminophen

The relative expression of CYP1A2 and COX-2 gene in the liver, no significant difference ( $p \geq 0.05$ ) was observed in the level of the gene expressed when all the groups were compared with basal and negative control groups as shown in Figures 1 and 2.

The relative expression of the GST gene in the liver, the group administered $200 \mathrm{mg} / \mathrm{kg}$ body weight of $B$. coriacea extract exhibited significant up-regulation $(\mathrm{p}<0.05)$ of GST gene. No significant $(p>0.05)$ difference was observed in the level of the gene expressed when all the remaining groups were compared with basal and negative control groups as shown in Figure 3.

The effect of Buchholzia coriacea extract and $\mathrm{N}$-acetylcysteine on the expression of Fasl gene in the liver of rats given sub-chronic dose of acetaminophen is shown in Figure 4. Statistical significant difference of down regulation $(\mathrm{p}<0.002)$ was observed in the level of Fasl gene expressed when the group treated with $14.29 \mathrm{mg} / \mathrm{kg}$ body weight of acetaminophen and $200 \mathrm{mg} / \mathrm{kg}$ body weight of Buchholzia coriacea was compared to basal and negative control groups. Also, there was a significant statistical difference of down regulation $(\mathrm{p}<0.033)$ when the group treated with $14.29 \mathrm{mg} / \mathrm{kg}$ body weight of acetaminophen and $400 \mathrm{mg} / \mathrm{kg}$ body weight of Buchholzia coriacea was compared with basal group only. In the other groups, there was no significant difference in the expression of Fasl gene.

As shown in Figure 5, there was significant down regulation $(p<0.002)$ in the relative gene expression of GPX-1 when the negative

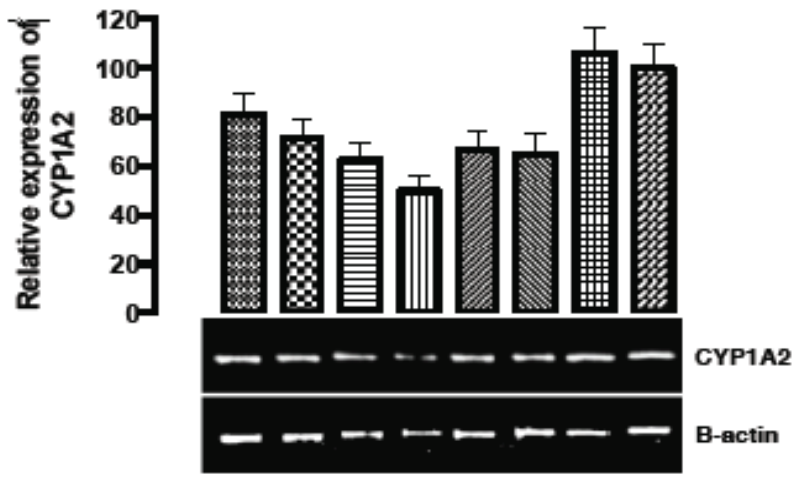

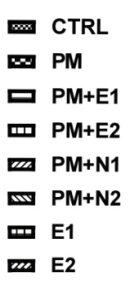

Figure 1: The effect of Buchholzia coriacea extract and $\mathrm{N}$-acetylcysteine on the expression of CYP1A2 gene in the pre-treatment (sub-chronic) stage of acetaminophen toxicity in liver of Wistar rats.

$\mathrm{PM}=14.28 \mathrm{mg} / \mathrm{kg}$ body weight of acetaminophen, $\mathrm{E} 1=200 \mathrm{mg} / \mathrm{kg}$ body weight of $B$ coriacea, $\mathrm{E} 2=400 \mathrm{mg} / \mathrm{kg}$ body weight of $B$ coriacea, $\mathrm{N} 1=70$ $\mathrm{mg} / \mathrm{kg}$ body weight of $\mathrm{N}$-acetylcysteine, $\mathrm{N2}=150 \mathrm{mg} / \mathrm{kg}$ body weight of $\mathrm{N}$-acetylcysteine.

$\mathrm{P}<0.05$, Turkey post hoc test, ${ }^{*} \mathrm{p}<0.033,{ }^{* *} \mathrm{p}<0.002, * * * \mathrm{p}<0.001$. 


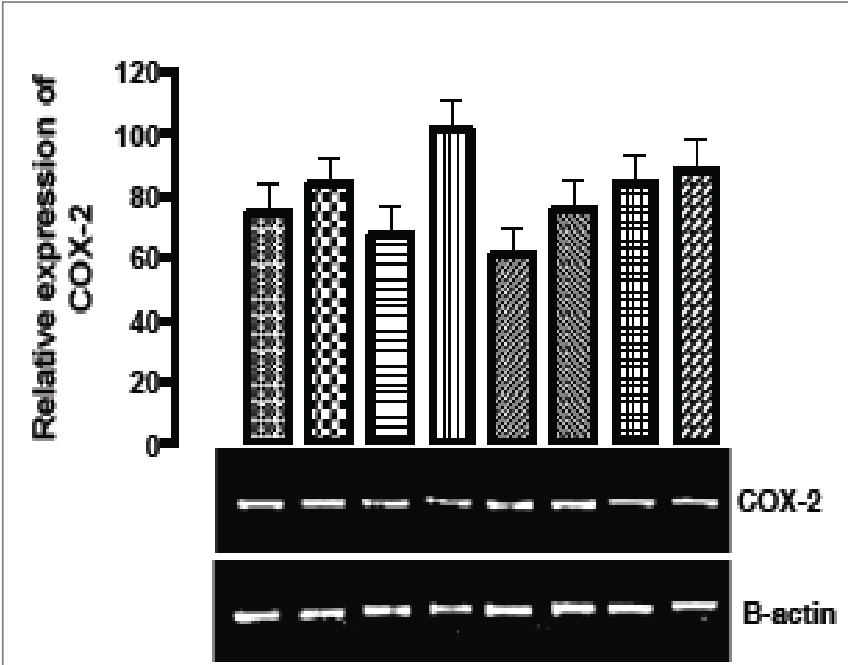

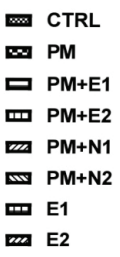

Figure 2: The effect of Buchholzia coriacea extract and $\mathrm{N}$-acetylcysteine on the expression of COX-2 gene in the pre-treatment (sub-chronic) stage of acetaminophen toxicity in liver of Wistar rats.

$\mathrm{PM}=14.28 \mathrm{mg} / \mathrm{kg}$ body weight of acetaminophen, $\mathrm{E} 1=200 \mathrm{mg} / \mathrm{kg}$ body weight of $B$ coriacea, $\mathrm{E} 2=400 \mathrm{mg} / \mathrm{kg}$ body weight of $B$ coriacea, $\mathrm{N} 1=70$ $\mathrm{mg} / \mathrm{kg}$ body weight of $\mathrm{N}$-acetylcysteine, $\mathrm{N} 2=150 \mathrm{mg} / \mathrm{kg}$ body weight of $\mathrm{N}$-acetylcysteine.

$\mathrm{P}<0.05$, Turkey post hoc test, ${ }^{*} \mathrm{p}<0.033,{ }^{* *} \mathrm{p}<0.002,{ }^{* * *} \mathrm{p}<0.001$. control was compared with basal control group. The groups treated with $14.28 \mathrm{mg} / \mathrm{kg}$ acetaminophen and $400 \mathrm{mg} / \mathrm{kg}$ extract, 200 and 400 $\mathrm{mg} / \mathrm{kg}$ extract were compared to the basal control, there was significant $(\mathrm{p}<0.002)$ up regulation in the level of GPx-1 gene. The group treated with $14.28 \mathrm{mg} / \mathrm{kg}$ acetaminophen showed significant down regulation $(\mathrm{p}<0.002)$ when compared with E1 and E2 groups. The remaining groups did not show any statistical significant difference $(p>0.05)$ when compared with basal control group.

Gene expression results of kidney pre-treated with subchronic dose of acetaminophen

The effect of Buchholzia coriacea extract compared to $\mathrm{N}$-acetylcysteine on expression of CYP1A2 gene in the kidney is illustrated in Figure 6. Statistically, there was no significant difference $(p>0.05)$ in the expression of CYP1A2 in the two groups when compared to basal and negative control groups.

The relative expression of the GST gene in the kidney is shown in Figure 7. The group administered $200 \mathrm{mg}>\mathrm{kg}$ b.w of B. coriacea extract exhibited significant up-regulation $(\mathrm{p}<0.001)$ of GST gene. While $\mathrm{P}+\mathrm{E} 1$ and $\mathrm{P}+\mathrm{E} 2$ groups showed significant down regulation $(\mathrm{p}<0.002)$ when compared with basal control group. No significant statistical ( $>0.05)$ difference was observed in the level of the gene expressed when all the remaining groups were compared with basal and negative control groups.

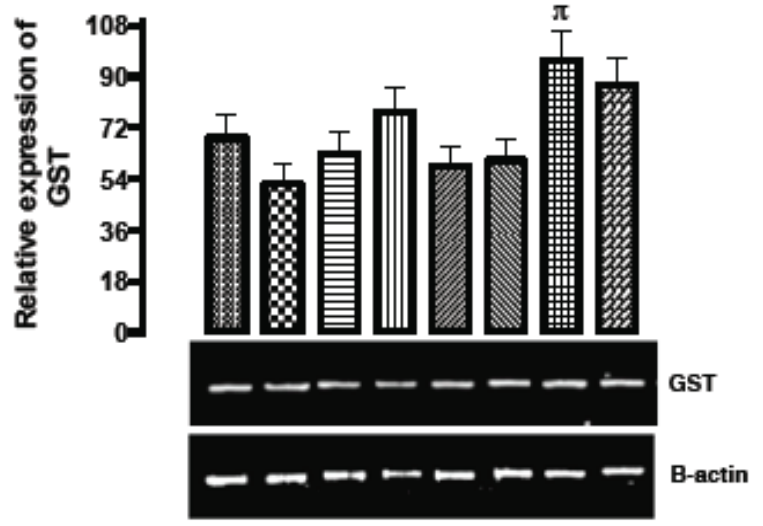

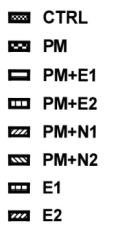

Figure 3: The effect of Buchholzia coriacea extract and N-Acetyl cysteine on the expression of GST gene in the pre-treatment (subchronic) stage of acetaminophen toxicity in liver of Wistar rats.

$\mathrm{PM}=14.28 \mathrm{mg} / \mathrm{kg}$ body weight of acetaminophen, $\mathrm{E} 1=200 \mathrm{mg} / \mathrm{kg}$ body weight of $B$ coriacea, E2 $=400 \mathrm{mg} / \mathrm{kg}$ body weight of $B$ coriacea, $\mathrm{N} 1=70$ $\mathrm{mg} / \mathrm{kg}$ body weight of $\mathrm{N}$-acetylcysteine, $\mathrm{N} 2=150 \mathrm{mg} / \mathrm{kg}$ body weight of $\mathrm{N}$-acetylcysteine.

$\mathrm{P}<0.05$, Turkey post hoc test, ${ }^{*} \mathrm{p}<0.033,{ }^{*} \mathrm{p}<0.002,{ }^{* * *} \mathrm{p}<0.001$.

The effect of Buchholzia coriacea extract compared to $\mathrm{N}$-acetylcysteine on the expression of GPx-1, fas ligand and interleukin- 6 gene in the kidneys of rats treated with sub chronic dose of acetaminophen is illustrated in Figures 8-10. There was no significant difference $(\mathrm{p}<0.05)$ in the gene expression levels in all the groups when compared with basal and negative control groups. In contrast, $\mathrm{PM}+\mathrm{E} 2$ group showed significant down regulation $(\mathrm{p}<0.002)$ when compared with basal control group.

The effect of Buchholzia coriacea extract compared to $\mathrm{N}$-acetylcysteine on the expression of KIM-1 gene in the kidney of rats treated with sub-chronic dose of acetaminophen is illustrated in Figure 11. There was significant down regulation $(\mathrm{p}<0.002)$ in the expression of KIM-1 gene and $\mathrm{PM}+\mathrm{E} 2$ group when compared with the basal control group. However, significant up regulation $(\mathrm{p}<0.001)$ of KIM-1 gene was observed in E2 group. The remaining groups did not show any significant difference $(\mathrm{p}>0.05)$ in the expression of the gene.

Figure 12 shows the effect of Buchholzia coriacea extract compared to $\mathrm{N}$-acetylcysteine on the expression of prostaglandin synthase gene. There was significant down regulation $(\mathrm{p}<0.002)$ in the expression of prostaglandin gene in $\mathrm{PM}+\mathrm{E} 2$ group when compared with the basal control group. The remaining groups did not show any significant difference $(p>0.05)$ in the expression of the gene. 


\section{Discussions}

The liver is a major organ in the human body with series of functions essential for wellbeing [38]. The use of pharmaceuticals: especially those synthesized from synthetic substances do have debilitating effects on organs like the liver and the kidneys, whose primary function is to metabolize xenobiotics and excrete their metabolic wastes [39]. Acute, sub-acute, sub-chronic and chronic doses of pharmaceuticals have been known to be injurious to health because of their adverse effects on these internal organs.

Acetaminophen is an antipyretic drug used in treating headaches, inflammation and as an adjuvant in fever treatment. Despite the versatility of acetaminophen, its overdose has been confirmed to affect kidneys and liver [40]. In lieu of this, the development of drugs that can be used to treat acetaminophen toxicity has drawn attention, partly due to its availability and tendency for its abuse.

Natural drug development from plants, have drawn the attention of researchers and drug manufacturing companies. This is because phytochemicals from plants are less expensive, have less retention time and more bioavailable, when compared to their synthetic counterparts [41]. The extract of $B$. coriacea has been used traditionally to treat some conditions. Recently, its potentials in treating toxicity induced by drug overdose have been expounded [42]. B. coriacea has been used in this research to treat acetaminophen toxicity compared to $\mathrm{N}$-acetylcysteine as the standard drug. The effect of the plant extract and $\mathrm{N}$-acetylcysteine on some expressed genes in the liver and kidneys

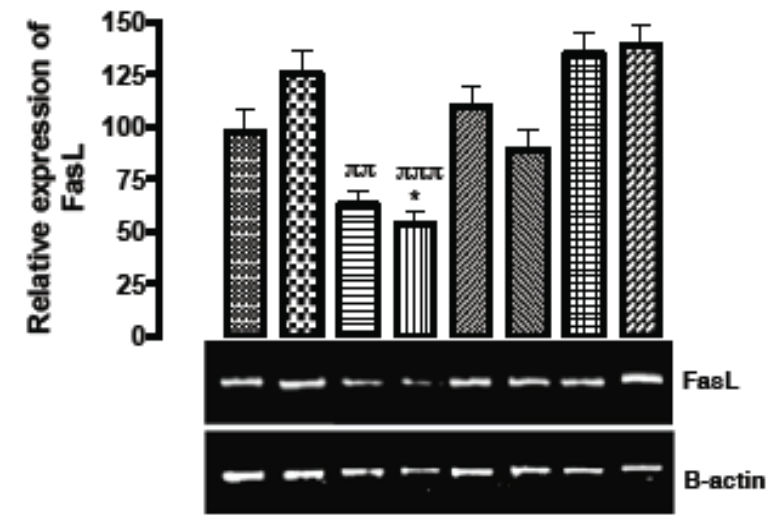

\footnotetext{
CTRL

四 PM

口 $\mathrm{PM}+\mathrm{E} 1$

吕 PM+E2

m $\mathrm{PM}+\mathrm{N} 1$

m $\mathrm{PM}+\mathrm{N} 2$

E1

E2
}

Figure 4: The effects of Buchholzia coriacea extract and $\mathrm{N}$-acetyl cysteine on the expression of FasL gene in the pre-treatment (subchronic) stage of acetaminophen toxicity in liver of Wistar rats.

$\mathrm{PM}=14.28 \mathrm{mg} / \mathrm{kg}$ body weight of acetaminophen, $\mathrm{E} 1=200 \mathrm{mg} / \mathrm{kg}$ body weight of $B$ coriacea, E2 $=400 \mathrm{mg} / \mathrm{kg}$ body weight of $B$ coriacea, $\mathrm{N} 1=70$ $\mathrm{mg} / \mathrm{kg}$ body weight of $\mathrm{N}$-acetylcysteine, $\mathrm{N} 2=150 \mathrm{mg} / \mathrm{kg}$ body weight of $\mathrm{N}$-acetylcysteine.

$\mathrm{P}<0.05$, Turkey post hoc test, ${ }^{*} \mathrm{p}<0.033,{ }^{* *} p<0.002,{ }^{* * *} \mathrm{p}<0.001$.

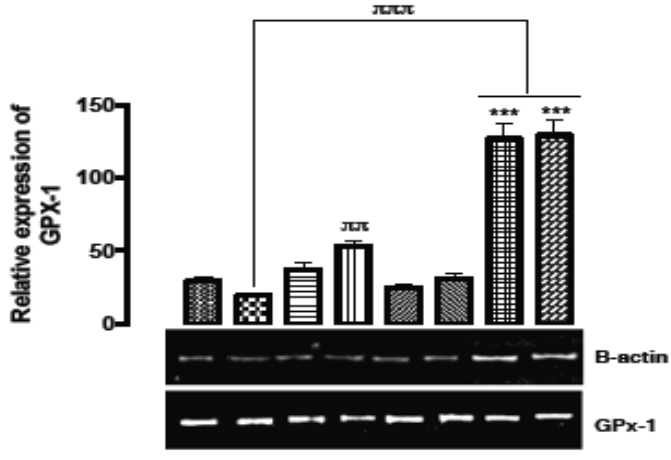

CTRL

DM

口 $\mathrm{PM}+\mathrm{E}$

미 PM+E2

mM+N1

西 $\mathrm{PM}+\mathrm{N} 2$

E1

Em

Figure 5: The effect of Buchholzia coriacea extract and N-Acetylcysteine on the expression of GPX-1 gene in the pre-treatment (sub-chronic) stage of acetaminophen toxicity in liver of Wistar rats.

$\mathrm{PM}=14.28 \mathrm{mg} / \mathrm{kg}$ body weight of acetaminophen, $\mathrm{E} 1=200 \mathrm{mg} / \mathrm{kg}$ body weight of $B$ coriacea, $\mathrm{E} 2=400 \mathrm{mg} / \mathrm{kg}$ body weight of $B$ coriacea, $\mathrm{N} 1=70$ $\mathrm{mg} / \mathrm{kg}$ body weight of $\mathrm{N}$-acetylcysteine, $\mathrm{N} 2=150 \mathrm{mg} / \mathrm{kg}$ body weight of $\mathrm{N}$-acetylcysteine.

$\mathrm{P}<0.05$, Turkey post hoc test, ${ }^{*} \mathrm{p}<0.033,{ }^{* *} \mathrm{p}<0.002,{ }^{* * *} \mathrm{p}<0.001$.

were investigated to determine the biochemical effects of extract of $B$. coriacea in acetaminophen sub-chronic administration.

There was a little repression of GST gene (Figure 3) in the group treated with acetaminophen only in comparison to the control. This repression could be as a result of the fact that $\mathrm{N}$-acetyl-p-benzoquinone imine (NAPQI), a metabolite of acetaminophen reacts with Glutathione (GSH), therefore sub-chronic dose of acetaminophen may result in a depletion of GSH from hepatocytes [43,21]. This is in concordance with the report of Daniel D, et al. [44] on Daphnia magna (a zooplanktonic microcrustacean found in freshwater environments) after a 21day exposure to acetaminophen. Their data showed an unexpected decrease in GST activity. A significant decrease was observed in GST activity in Asian clam, Corbicula fluminea following short-term and long term exposure to acetaminophen [45]. Henderson CJ, et al. [46] showed that GST Pi, the principal GST isoform of acetaminophen metabolism in humans and rats, is significantly decreased in rat liver after being exposed to acetaminophen. GSTs might not be the principal mechanism of detoxification of this drug [44]. Administration of B. coriacea extract only $(200 \mathrm{mg} / \mathrm{kg} \mathrm{b}$. w) up regulates the mRNA expression of GST. This will in turn lead to increased GSH levels in the body, hence enhance cytoprotection. Sub-chronic administration of acetaminophen with the extract leads to slight up-regulation of GST gene. In a research by Somanawat $\mathrm{K}$ and colleagues [23], curcumin has been screened to possess hepatoprotective properties against liver damage in male mice by restoring hepatic GSH in hepatic toxicity induced by acetaminophen overdose. Curcumin was reported to protect against oxidative stress mediated by free radicals. Curcumin is said to scavenge free radicals and ameliorates antioxidants depletion 


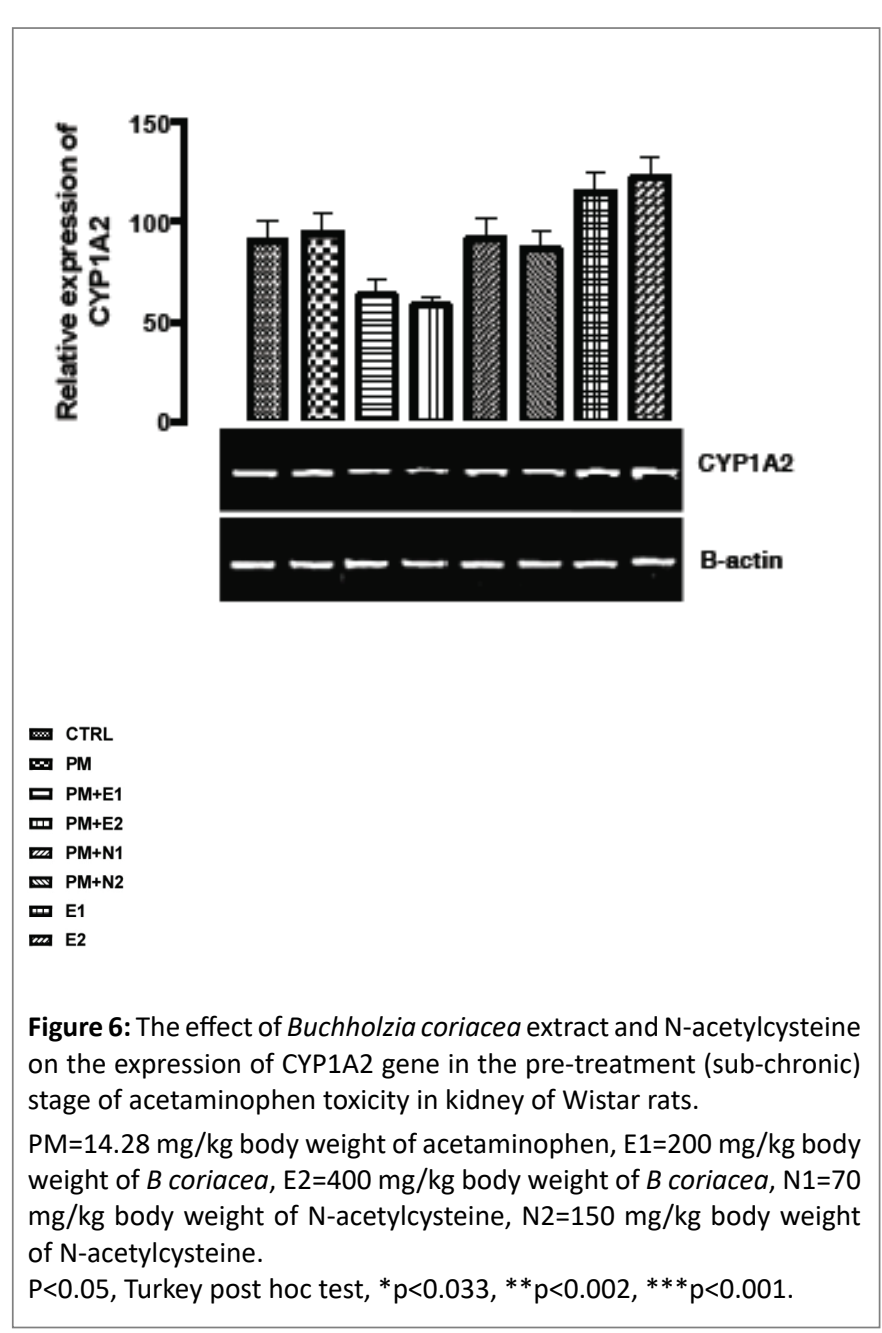

by increasing mRNA expressions of GST in hepatic toxicity induced by acetaminophen. Hence, the ethanolic extract of $B$. coriacea might also possess similar antioxidant ability by blocking the depletion of GSH by increasing mRNA expressions of GST in hepatic tissue after toxicity with sub-chronic dose of acetaminophen. Administration of acetaminophen with the extract significantly reduced GST gene expression (Figure 7). This could be that the extract was unable to reverse the repressive effect of acetaminophen on GST gene, and therefore explore another means of cytoprotection in the kidneys. According to Franco R, et al. [47], the expression of GST gene must be up-regulated in normal kidneys so as to be able to detoxify harmful substances. However, the results from the effect of the plant extract in the kidneys of the group treated with $200 \mathrm{mg} / \mathrm{kg}$ body weight of extract depicted up-regulation of GST gene. Hence, the extract of Buchholzia coriacea at this dose, was able to induce increase in expression of GST gene for detoxification of harmful chemicals in the kidneys.

From the results obtained in our research, the ethanolic extract of Buchholzia coriacea might possess the ability to inhibit the transcriptional expression and activity of hepatic CYP1A2 as shown in Figures 1 and 6. The extract elicited potentials for mitigating acetaminophen-induced toxicity by inhibiting over expression of CYP1A2 (PM+E1 and PM+E2 groups). However, acetaminophen did not promote mRNA expression of CYP1A2 in the study. This may be that it involves and probably induces other isoforms of CYP to metabolize acetaminophen to NAPOI.

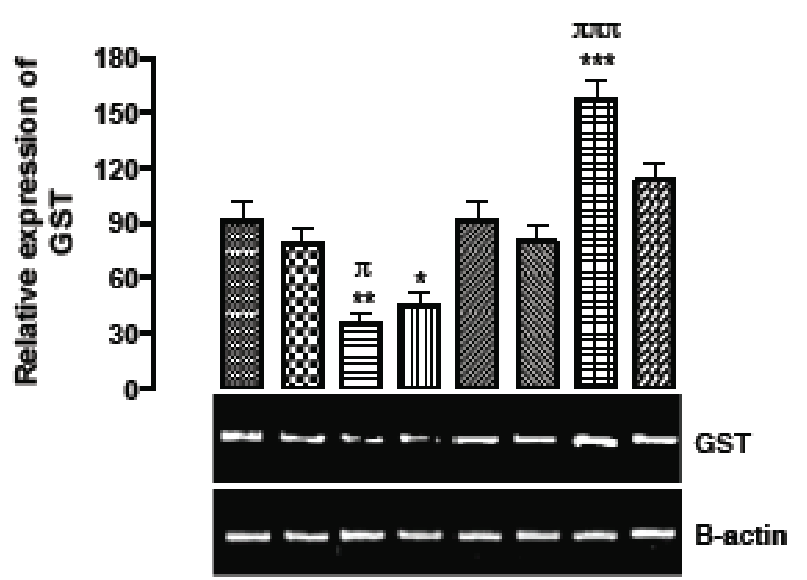

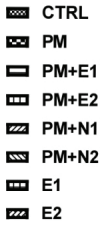

Figure 7: The effect of Buchholzia coriacea extract and N-acetylcysteine on the expression of GST gene in the pre-treatment (sub-chronic) stage of acetaminophen toxicity in kidney of Wistar rats.

$\mathrm{PM}=14.28 \mathrm{mg} / \mathrm{kg}$ body weight of acetaminophen, $\mathrm{E} 1=200 \mathrm{mg} / \mathrm{kg}$ body weight of $B$ coriacea, E2 $=400 \mathrm{mg} / \mathrm{kg}$ body weight of $B$ coriacea, $\mathrm{N} 1=70$ $\mathrm{mg} / \mathrm{kg}$ body weight of $\mathrm{N}$-acetylcysteine, $\mathrm{N} 2=150 \mathrm{mg} / \mathrm{kg}$ body weight of $\mathrm{N}$-acetylcysteine.

$\mathrm{P}<0.05$, Turkey post hoc test, ${ }^{*} \mathrm{p}<0.033,{ }^{*} \mathrm{p}<0.002, * * * p<0.001$.

From our result, it could be suggested that the ethanolic extract of B. coriacea might be a weak inhibitor of COX-2 mRNA expression compared to acetaminophen (Figure 2), since there was no significant difference in the expression of COX-2 among the treated groups. However, the plant may possess anti-inflammatory activity $(\mathrm{PM}+\mathrm{E} 1$, Figure 2), and that might be responsible for slight down-regulation seen in the gene expression of COX-2 in the group. Ogechukwu UB, et al. [48] demonstrated that the methanolic extract of Buchholzia coriacea seed (wonderful kola) contains anti-inflammatory activity. In liver diseases such as cirrhosis or hepatitis, up-regulation of COX2 gene is observed. Acetaminophen treatment induced consistent mRNA expression changes in COX-2 levels [49]. However, in severe inflammation gets out of control (such as in the case of arthritis, or other chronic inflammatory disorders) it results in pain and discomfort. Slight (non-significant) up regulation of CYP1A2 gene was found in the extract alone groups (E1 and E2, Figure 2). This might be an attempt to protect the body against possible inflammation, a normal, healthy attempt by the body to heal itself.

The soluble form of FasL was reported to have both apoptotic and pro-inflammatory activities in immune cells [50]. Administration of sub-chronic dose of acetaminophen alone, in this study, caused slight increase in mRNA expression of Fas ligand when compared with normal control groups (Figures 4 and 9). This suggests how sub-chronic dose of acetaminophen may lead to kidney injury and, studies have shown that the ligation of Fas with FasL results in the activation of a 
caspase cascade that initiates apoptosis, which occurs from normal cell aging or as a result of cellular injury [51]. Co-administration of subchronic dose of acetaminophen with the extract $(\mathrm{PM}+\mathrm{E} 1$ and $\mathrm{PM}+\mathrm{E} 2$ groups, Figures 4 and 9) caused significant repression $(\mathrm{p}<0.033)$ in mRNA expression of Fas ligand, although, no significant difference was seen in the other groups (Figures 4 and 9). This correlates with the investigation carried out by Ogechukwu UB, et al. [48]. It was demonstrated that the methanolic extract and the aqueous extract of $B$. coriacea possessed a comparable anti-inflammatory activity. These results also agree with the study carried out by Wang Q and co-researchers [52] on the effect of Naringin on the expression level of apoptosis related genes where treatment with Naringin markedly decreased the level of fas ligand gene in the kidneys. Therefore, based on this experiment, treatment with the extract of $B$. coriacea presented it as a good antidote to reduce liver and kidney cell injury that can lead to apoptosis by inhibiting FasL gene.

Administration of Buchholzia coriacea extract only before treatment with acetaminophen caused a significant up-regulation of GPX-1 gene (PM+E1, PM+E2, E1 and E2; Figure 5). The plant therefore demonstrates the potential to replenish and attenuate antioxidant depletion of GSH in the body. According to Morsy MA, et al. [53] curcumin possesses the ability to lower effects of $\mathrm{CCl}_{4}$ in animals induced by carbon tetrachloride, and also curcumin lowers hepatotoxicity induced by aflatoxin B [54]. Curcumin increased mRNA expressions of GPX, attenuates antioxidants depletion and

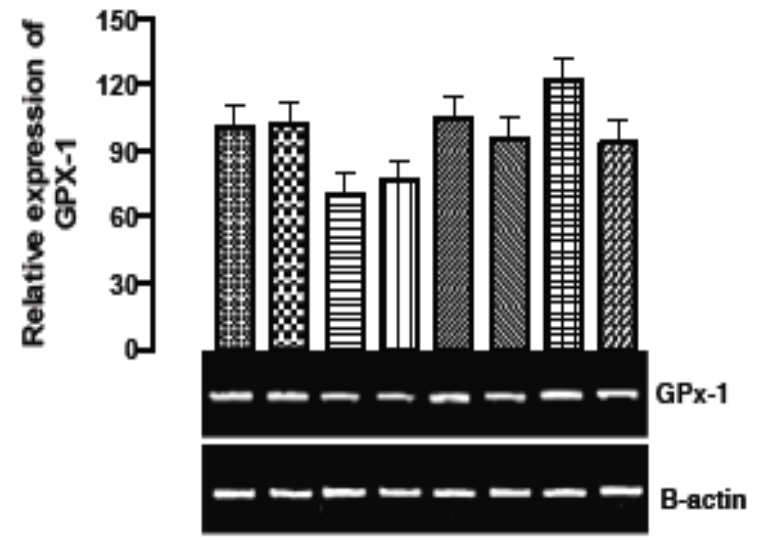

\footnotetext{
m CTRL

DPM

口 $\mathrm{PM}+\mathrm{E} 1$

囬M+E2

m $\mathrm{PM}+\mathrm{N} 1$

四 $\mathrm{PM}+\mathrm{N} 2$

$\mathrm{E} 1$

E2
}

Figure 8: The effect of Buchholzia coriacea extract and $\mathrm{N}$-acetylcysteine on the expression of GPX-1 gene in the pre-treatment (sub-chronic) stage of acetaminophen toxicity in kidney of Wistar rats.

$P M=14.28 \mathrm{mg} / \mathrm{kg}$ body weight of acetaminophen, $E 1=200 \mathrm{mg} / \mathrm{kg}$ body weight of $B$ coriacea, $\mathrm{E} 2=400 \mathrm{mg} / \mathrm{kg}$ body weight of $B$ coriacea, $\mathrm{N} 1=70$ $\mathrm{mg} / \mathrm{kg}$ body weight of $\mathrm{N}$-acetylcysteine, $\mathrm{N} 2=150 \mathrm{mg} / \mathrm{kg}$ body weight of $\mathrm{N}$-acetylcysteine.

$\mathrm{P}<0.05$, Turkey post hoc test, ${ }^{*} \mathrm{p}<0.033,{ }^{* *} \mathrm{p}<0.002,{ }^{* * *} \mathrm{p}<0.001$.

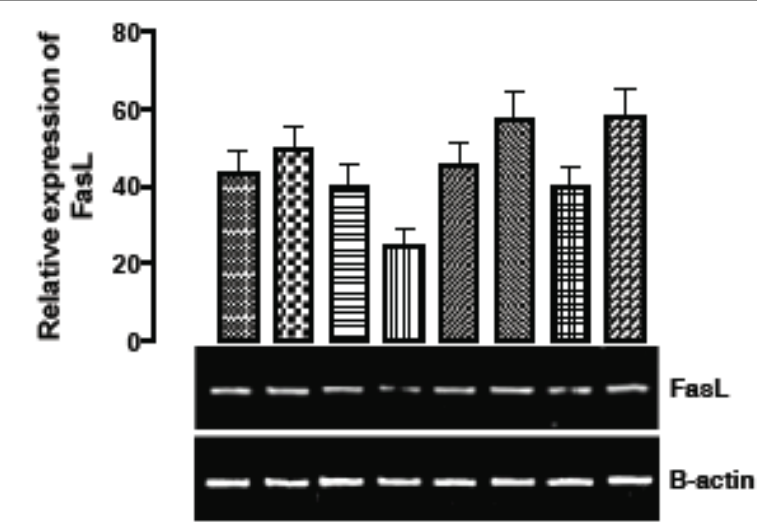

$\mathrm{m}$ CTRL

DPM

口 PM+E1

吕 $\mathrm{PM+E2}$

m $\mathrm{PM}+\mathrm{N} 1$

m $\mathrm{PM}+\mathrm{N} 2$

四1

m2

Figure 9: The effect of Buchholzia coriacea extract and N-acetylcysteine on the expression of FasL gene in the pre-treatment (sub-chronic) stage of acetaminophen toxicity in kidney of Wistar rats.

$\mathrm{PM}=14.28 \mathrm{mg} / \mathrm{kg}$ body weight of acetaminophen, $\mathrm{E} 1=200 \mathrm{mg} / \mathrm{kg}$ body weight of $B$ coriacea, E2 $=400 \mathrm{mg} / \mathrm{kg}$ body weight of $B$ coriacea, $\mathrm{N} 1=70$ $\mathrm{mg} / \mathrm{kg}$ body weight of $\mathrm{N}$-acetylcysteine, $\mathrm{N} 2=150 \mathrm{mg} / \mathrm{kg}$ body weight of $\mathrm{N}$-acetylcysteine.

$\mathrm{P}<0.05$, Turkey post hoc test, ${ }^{*} \mathrm{p}<0.033,{ }^{* *} \mathrm{p}<0.002, * * * \mathrm{p}<0.001$.

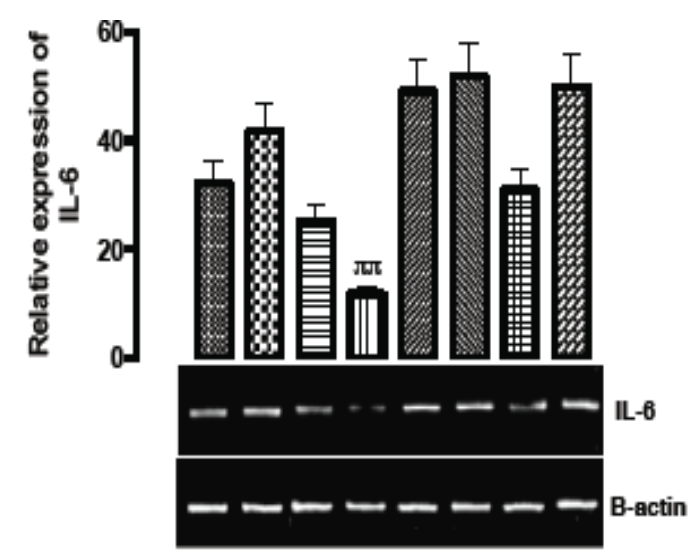

$$
\begin{aligned}
& \text { ․․ CTRL } \\
& \text { 四 PM } \\
& \text { 口 } \mathrm{PM}+\mathrm{E} 1 \\
& \text { 四 PM+E } \\
& \text { 四 PM+E2 } \\
& \text { m } \mathrm{PM}+\mathrm{N} 1 \\
& \text { m1 } \\
& \text { m2 }
\end{aligned}
$$

Figure 10: The effect of Buchholzia coriacea extract and $\mathrm{N}$-acetylcysteine on the expression of IL- 6 gene in the pre-treatment (sub-chronic) stage of acetaminophen toxicity in kidney of Wistar rats. $\mathrm{PM}=14.28 \mathrm{mg} / \mathrm{kg}$ body weight of acetaminophen, $\mathrm{E} 1=200 \mathrm{mg} / \mathrm{kg}$ body weight of $B$ coriacea, E2 $=400 \mathrm{mg} / \mathrm{kg}$ body weight of $B$ coriacea, N1=70 $\mathrm{mg} / \mathrm{kg}$ body weight of $\mathrm{N}$-acetylcysteine, $\mathrm{N} 2=150 \mathrm{mg} / \mathrm{kg}$ body weight of $\mathrm{N}$-acetylcysteine.

$\mathrm{P}<0.05$, Turkey post hoc test, ${ }^{*} p<0.033,{ }^{*} \mathrm{p}<0.002, * * * p<0.001$. 

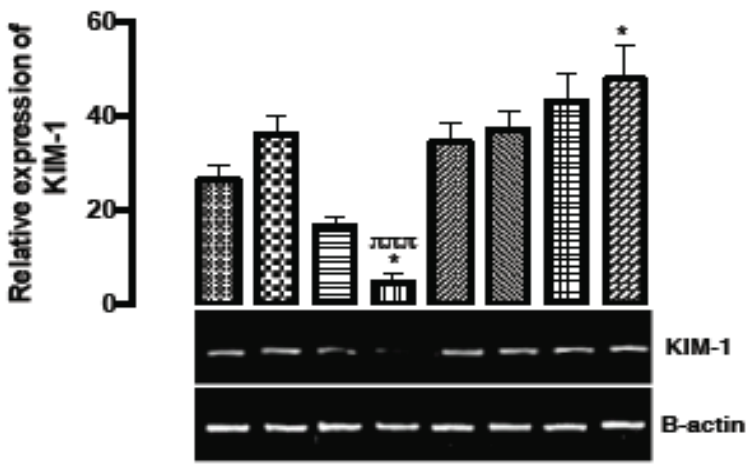

\section{$\square$ CTRL \\ D PM \\ 口 $\mathrm{PM}+\mathrm{E} 1$ \\ 吕 $\mathrm{PM}+\mathrm{E}_{2}$ \\ m $\mathrm{PM}+\mathrm{N}$ \\ 西 $\mathrm{PM}+\mathrm{N}$ \\ 四1 \\ m2}

Figure 11: The effect of Buchholzia coriacea extract and $\mathrm{N}$-acetylcysteine on the expression of KM-1 gene in the pre-treatment (sub-chronic) stage of acetaminophen toxicity in kidney of Wistar rats. $\mathrm{PM}=14.28 \mathrm{mg} / \mathrm{kg}$ body weight of acetaminophen, $\mathrm{E} 1=200 \mathrm{mg} / \mathrm{kg}$ body weight of $B$ coriacea, $\mathrm{E} 2=400 \mathrm{mg} / \mathrm{kg}$ body weight of $B$ coriacea, $\mathrm{N} 1=70$ $\mathrm{mg} / \mathrm{kg}$ body weight of $\mathrm{N}$-acetylcysteine, $\mathrm{N} 2=150 \mathrm{mg} / \mathrm{kg}$ body weight of $\mathrm{N}$-acetylcysteine.

$\mathrm{P}<0.05$, Turkey post hoc test, ${ }^{*} \mathrm{p}<0.033,{ }^{* *} \mathrm{p}<0.002,{ }^{* * *} \mathrm{p}<0.001$.

protects the liver from acetaminophen overdose-induced toxicity [21]. It was stated that Phytosome curcumin had a strong protective effect against acetaminophen-induced acute renal damage in mice and the nephroprotective effect of Phytosome curcumin may be explained by increasing levels of antioxidant enzymes and decreasing the lipid peroxidation on acetaminophen-induced damage in mice [55]. However, the effects of acetaminophen, Buchholzia coriacea extract and $\mathrm{N}$-acetylcysteine on the expression of GPx-1 gene in the kidneys of rats was not significantly different from each other (Figure 8). Phytochemicals from Buchholzia coriacea have been described as free radical scavengers [56]. The results in this work show that Buchholzia coriacea extract increased mRNA expressions of GPx-1, attenuated antioxidants depletion, protected the liver from acetaminopheninduced toxicity, and effectively prevented nephrotoxicity that can result from acetaminophen.

The expression of KIM-1 mRNA was previously reported to be markedly induced in rats in response to renal injury caused by cisplatin [57]. Likewise, in this study (Figure 11), Buchholzia coriacea was able to repress the expression of KIM-1 mRNA induced in rats in response to renal injury caused by the effect of acetaminophen. We can conclude that Buchholzia coriacea may be effective in preventing nephropathy induced by acetaminophen toxicity. However, administration of the extract alone at $400 \mathrm{mg} / \mathrm{kg}$ (E2, Figure 11) elicited over expression of KIM-1 gene. This may imply that a higher dose of Buchholzia coriacea extract may not be toxic or a pro-oxidant.

Acetaminophen is classified as a mild analgesic [2] and does not have significant anti-inflammatory activity [58]. There was slight

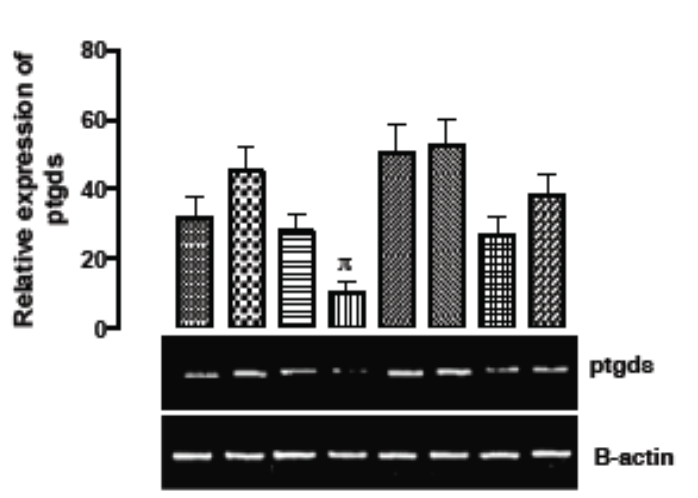

max CTRL

D. PM

口 $\mathrm{PM}+\mathrm{E} 1$

四 PM+E2

m $\mathrm{PM}+\mathrm{N} 1$

m $\mathrm{PM}+\mathrm{N} 2$

E1

Figure 12: The effect of Buchholzia coriacea extract and $\mathrm{N}$-acetylcysteine on the expression of Ptgds gene in the pre-treatment (sub-chronic) stage of acetaminophen toxicity in kidney of Wistar rats.

$\mathrm{PM}=14.28 \mathrm{mg} / \mathrm{kg}$ body weight of acetaminophen, $\mathrm{E} 1=200 \mathrm{mg} / \mathrm{kg}$ body weight of $B$ coriacea, $\mathrm{E} 2=400 \mathrm{mg} / \mathrm{kg}$ body weight of $B$ coriacea, $\mathrm{N} 1=70$ $\mathrm{mg} / \mathrm{kg}$ body weight of $\mathrm{N}$-acetylcysteine, $\mathrm{N} 2=150 \mathrm{mg} / \mathrm{kg}$ body weight of $\mathrm{N}$-acetylcysteine.

$\mathrm{P}<0.05$, Turkey post hoc test, $95.00 \% \mathrm{CL} * \mathrm{p}<0.033, * * \mathrm{p}<0.002$, $* * * p<0.001$.

increase above the normal control group in the level of prostaglandin synthase gene in the group treated with acetaminophen (Figure 12). Buchholzia coriacea was able to repress mRNA expression of prostaglandin gene $(\mathrm{PM}+\mathrm{E} 2$, Figure 12). Buchholzia coriacea therefore has anti-inflammatory properties (Figure 12). In this study, $\mathrm{N}$-acetylcysteine did not alter the expression of prostaglandin synthase gene from the normal control group (Figure 12). This is in accordance with the research of Dimari J, et al. [59], on clinical trials that suggested that $\mathrm{N}$-acetylcysteine replenishes glutathione stores, scavenges hydroxyl free radicals and also has anti-inflammatory properties which is confirmed in the study carried out by Ancha $\mathrm{HR}$ and co-worker [60] where treatment with NAC suppressed prostaglandin synthase expression to control values in TNBS-induced colitis in rats. The expression pattern of prostaglandin synthase gene from the result shows that Buchholzia coriacea extract was able to elicit physiological effect on diseased kidneys. The extract of $B$. coriacea can serve as a natural potent anti-inflammatory agent and as an adjuvant, could be a good reparative drug in treating kidney injury. This agrees with the work of Xing C-Y, et al. [61] in which dexamethasone and vitamin D repressed IL-6 gene expression, which partially accounts for its anti-inflammation effects. Expression of IL-6 gene is lowered in normal kidneys since it promotes inflammation in the kidneys. Research has shown that ethanolic extract of $B$. coriacea leaf proved to have anti-inflammatory potential which could be attributed to phytochemical components acting individually or collectively as seen in some of the groups treated with extract [62]. Buchholzia coriacea extract has been proven to have a higher rate of antioxidant and anti- 
inflammatory properties [63]. From our results, the down-regulation in the group treated with acetaminophen and $400 \mathrm{mg} / \mathrm{kg}$ of Buchholzia coriacea extract (Figure 10) might portray B. coriacea as a potent antiinflammatory agent.

\section{Conclusion}

Based on the present study, Buchholzia coriacea demonstrated protective ability against pro-oxidant and inflammatory properties of acetaminophen. Buchholzia coriacea seed could be studied for its possible antigenotoxic and biosafety before being considered for clinical trials as potent cytoprotective agent in the treatment of acetaminophen induced hepatorenal toxicities.

\section{Acknowledgements}

We are grateful to all the researchers at the Centre for Biocomputing and Drug Development Unit (CBDD), and the Department of Biochemistry, Faculty of Science of Adekunle Ajasin University, Akungba Akoko, Ondo State, Nigeria, for their support during this research work.

\section{References}

1. Lewis JH, Stine JG (2013) Review article: prescribing medications in patients with cirrhosis-a pratical guide. Aliment Pharmacol Ther 37: 1132-1156.

2. Tobias J, Hochhauser D (2014) Cancer and its Management. WileyBlackwell, United States.

3. Perrott DA, Piira T, Goodenough B, Champion GD (2004) Efficacy and safety of acetaminophen $v$ ibuprofen for treating children's pain or fever: a meta-analysis. Arch Pediatr Adolesc Med 158: 521-526.

4. Mattia C, Coluzzi F (2009) What anesthesiologists should know about paracetamol (acetaminophen). Mineral Anestesiol 75: 644653.

5. Murnion BP (2010) Combination analgesics in adults. Aust Prescr 33: 113-115.

6. Baumgardner JN, Shankar K, Hennings L, Albano E, Badger TM, et al. (2008) N-acetylcysteine attenuates progression of liver pathology in a rat model of nonalcoholic steatohepatitis. J Nutr 138: 1872-1879.

7. Shen H, Li M, Wang B, Lai IK, Robertson LW, et al. (2014) Dietary antioxidants (selenium and $\mathrm{N}$-acetylcysteine) modulate paraoxonase 1 (PON1) in PCB 126-exposed rats. Environ Sci Pollut Res Int 21: 6384-6399.

8. Thong-Ngam D, Samuhasaneeto S, Kulaputana O, Klaikeaw N (2007) $\mathrm{N}$-acetylcysteine attenuates oxidative stress and liver pathology in rats with non-alcoholic steatohepatitis. World J Gastroenterol 13: 5127-5132.

9. Dodd S, Dean O, Copolov DL, Malhi GS, Berk M (2008) $\mathrm{N}$-acetylcysteine for antioxidant therapy: pharmacology and clinical utility. Expert Opin Biol Ther 8: 1955-1962.

10. Daly FFS, Fountain JS, Murray L, Graudins A, Buckley NA, et al. (2008) Guidelines for the management of paracetamol poisoning in Australia and New Zealand-explanation and elaboration. A consensus statement from clinical toxicologists consulting to the Australasian poisons information centres. Med J Aust 188: 296-301.

11. Ferner RE, Dear JW, Bateman DN (2011) Management of paracetamol poisoning. BMJ 342: d2218.

12. Szkolnicka D, Lucendo-Villarin B, Moore JK, Simpson KJ, Forbes SJ, et al. (2016) Reducing Hepatocyte Injury and Necrosis in Response to Paracetamol Using Noncoding RNAs. Stem Cells Transl Med 5: 764-772.
13. Lee WM (2012) Acute liver failure. Semin Respir Crit Care Med 33: 36-45.

14. Bhushan B, Poudel S, Manley MW Jr, Roy N, Apte U (2017) Inhibition of Glycogen Synthase Kinase 3 Accelerated Liver Regeneration after Acetaminophen-Induced Hepatotoxicity in Mice. Am J Pathol 187: 543-552.

15. Lancaster EM, Hiatt JR, Zarrinpar A (2015) Acetaminophen hepatotoxicity: an updated review. Arch Toxicol 89: 193-199.

16. Jaeschke H, McGill MR, Ramachandran A (2012) Oxidant stress, mitochondria, and cell death mechanisms in drug-induced liver injury: lessons learned from acetaminophen hepatotoxicity. Drug Metab Rev 44: 88-106.

17. Bhushan B, Edwards G, Desai A, Michalopoulos GK, Apte U (2016) Liver-Specific Deletion of Integrin-Linked Kinase in Mice Attenuates Hepatotoxicity and Improves Liver Regeneration after Acetaminophen Overdose. Gene Expr 17: 35-45.

18. Xu S, Liu J, Shi J, Wang Z, Ji L (2017) 2,3,4',5-tetrahydroxystilbene-2-O$\beta$-D-glucoside exacerbates acetaminophen-induced hepatotoxicity by inducing hepatic expression of CYP2E1, CYP3A4 and CYP1A2. Sci Rep 7: 16511.

19. Song F, Hua F, Li H, Zhou X, Yan L, et al. (2016) Cardiac stem cell transplantation with 2,3,5,4'-tetrahydroxystilbehe-2-O- $\beta$-dglucoside improves cardiac function in rat myocardial infarction model. Life sci 158: 37-45.

20. Jóźwiak-Bebenista M, Nowak JZ (2014) Paracetamol: mechanism of action, applications and safety concern. Acta Pol Pharm 71: 11-23.

21. Soliman MM, Nassan MA, Ismail TA (2014) Immunohistochemical and molecular study on the protective effect of curcumin against hepatic toxicity induced by paracetamol in wistar rats. BMC Complement Altern Med 14: 457.

22. Jurenka JS (2009) Anti-inflammatory properties of curcumin, a major constituent of Curcuma longa: a review of preclinical and clinical research. Altern Med Rev 14: 141-153.

23. Somanawat K, Thong-Ngam D, Klaikeaw N (2013) Curcumin attenuated paracetamol overdose induced hepatitis. World J Gastroenterol 19: 1962-1967.

24. Jameson JL, Loscalzo J (2016) Harrison's Nephrology and Acid-base Disorders, 3e. McGraw-Hill 3-10.

25. Galley HF (2007) Can acute renal failure be prevented? J R Coll Surg Edinb 45: 44-50.

26. Gbagbeke KO, Naiho AO, Okonkwo BC, Omoirri MA, Emojevwe V, et al. (2018) Hepatic, Pancreatic, and Renal Histo-Morphologic Alterations in Administration of Aqueous and Ethanol Seed Extract of Buchholzia coriacea in Alloxan-Induced Diabetic Rats. Asian Journal of Medicine and Health 12: 1-11.

27. Okoye TC, Akah PA, llogu CL, Ezike AC, Onyeto CA (2012) Anti-diabetic Effects of Methanol Extract of the Seeds of Buchholzia coriacea and its Synergistic Effects with Metformin. Asian Journal of Biomedical and Pharmaceutical Sciences 2: 32-36.

28. Nweze NE, Fakae LB, Asuzu IU (2009) Trypanocidal Activity of the Ethanolic Extract of Buchholzia Coriacea Seed. Nigerian Veterinary Journal 29: 1-6.

29. Okoli BJ, Okere, OS, Adeyemo SO (2010) The Antiplasmodial Activity of Buchholzia coriacea. Journal of medical and applied Biosciences 2: 21-29. 
30. Mbata TI, Duru CM, Onwumelu HA (2009) Antibacterial activity of crude seed extracts of Buchholzia coriacea $E$. on some pathogenic bacteria. Journal of Developmental Biology and Tissue Engineering 1: 1-5.

31. Adediwura FJ, Omonike O, Olamide A, Oluwatosin E (2011) Larvicidal Effect of the Pet. Ether, Chloroform Fractions and Methanol Extract of Buccholzia Coriacea Engle Seed. IJPSR 2: 1736-1739.

32. Anowi CF, Ike C, Ezeokafor E, Ebere C (2012) The Phytochemical, Antispamodic and Antidiarrhoea Properties of the Methanol Extract of the Leaves of Buchholzia Coriacea Family Capparaceae. Int J Curr Pharm Res 4: 52-55.

33. MI Ezeja, II Ezeigbo, KG Madubuike (2011) Analgesic activity of the methanolic seed extract of Buchholzia coriacea. 2: 187-193.

34. Nweze NE, Asuzu IU (2006) The Anthelmintic Effects of Buchholzia coriacea Seed. Nigerian Veterinary Journal 27: 60-65.

35. Chika E, Blessing U, Ifeanyichukwu I, Malachy U, Charles E (2014) Phytochemical and antibacterial screening of crude extracts from leaves of Wonderful Kola. American Journal of Life Sciences 2: 9-12.

36. Giami SY, Bakebain DA (1992) Proximate composition of full fat fluted pumpkin (Telfairia occidentalis) seed flour. Journal of the Science of Food and Agriculture 59: 321-325.

37. Burgmann H, Widmer F, Sigler WV, Zeyer J (2003) mRNA extraction and reverse transcription-PCR protocol for detection of nifH gene expression by Azotobacter vinelandii in Soil. Appl Environ Microbiol 69: 1928-1935.

38. Kumar V, Robbins SL, Abbas AK, Fausto N (2005) Robbins and Cotran Pathologic Basis of Disease Elsevier/Saunders, United States.

39. Tao L, Bhushan V (2013) First Aid for the USMLE Step 12020. McGraw-Hill Education, United States.

40. Ghanem Cl, Pérez MJ, Manautou JE, Mottino AD (2016) Acetaminophen from liver to brain: New insights into drug pharmacological action and toxicity. Pharmacol Res 109: 119-131.

41. Ikpeazu OV, Otuokere IE, Igwe KK (2017) Preliminary Studies on the Secondary Metabolites of Buchholzia coriacea (Wonderful Kola) Seed Ethanol Extract by GC-MS Analysis. International Journal of Research in Engineering and Applied Sciences 7: 17-26.

42. Green JL, Heard KJ, Reynolds KM, Albert D (2013) Oral and Intravenous Acetylcysteine for Treatment of Acetaminophen Toxicity: A systematic Review and Meta-analysis. West J Emerg Med 14: $218-226$

43. Hinson JA, Reid AB, McCullough SS, James LP (2004) Acetaminopheninduced hepatotoxicity: role of metabolic activation, reactive oxygen/nitrogen species, and mitochondrial permeability transition. Drug Metab Rev 36: 805-822.

44. Daniel D, Dionísio R, de Alkimin GD, Nunes B (2019) Acute and chronic effects of paracetamol exposure on Daphnia magna: how oxidative effects may modulate responses at distinct levels of organization in a model species. Environ Sci Pollut Res Int 26: 33203329.

45. Brandão FP, Pereira JL, Gonçalves F, Nunes B (2014) The impact of paracetamol on selected biomarkers of the mollusc species Corbicula fluminea. Environ Toxicol 29: 74-83.

46. Henderson $\mathrm{CJ}$, Wolf $\mathrm{CR}$, Kitteringham $\mathrm{N}$, Powell $\mathrm{H}$, Otto $\mathrm{D}$, et al. (2000) Increased resistance to acetaminophen hepatotoxicity in mice lacking glutathione S-transferase Pi. Proc Natl Acad Sci U S A 97: 12741-12745.
47. Franco R, Schoneveld OJ, Pappa A, Panayiotidis MI (2007) The centra role of glutathione in the pathophysiology of human diseases. Arch Physiol Biochem 113: 234-258.

48. Ogechukwu UB, Chika A, Peter E, Daniel A, Afamefule OF (2016) Antimicrobial, Anti-inflammatory, and Chemical Evaluation of Buchholzia Coriacea Seed (Wonderful Kola). American Journal of Life Sciences 4: 106-112.

49. Suciu M, Gruia AT, Nica DV, Azghadi SMR, Mic AA, et al. (2015) Acetaminophen-induced liver injury: Implications for temporal homeostasis of lipid metabolism and eicosanoid signaling pathway. Chem Biol Interact 242: 335-344.

50. O'Reilly LA, Tai L, Lee L, Kruse EA, Grabow S, et al. (2009) Membranebound but not Secreted Fas Ligand Is Essential for Fas-Induced Apoptosis and Prevention of Autoimmunity and Cancer. Nature 461: 659-663.

51. Wolf BB, Green DR (2006) Suicidal tendencies: apoptotic cell death by caspase family proteinases. J Biol Chem 274: 20049-20052.

52. Wang Q, He Y, Shen Y, Zhang Q, Chen D, et al. (2017) Vitamin D inhibits COX-2 expression and inflammatory response by targeting thioesterase superfamily member 4. J Biol Chem 289: 11681-11694.

53. Morsy MA, Abdalla AM, Mahmoud AM, Abdelwahab SA, Mahmoud ME (2012) Protective effects of curcumin, $\alpha$-lipoic acid, and $\mathrm{N}$-acetylcysteine against carbon tetrachloride-induced liver fibrosis in rats. J Physiol Biochem 68: 29-35.

54. El-Agamy DS (2010) Comparative effects of curcumin and resveratrol on aflatoxin B(1)-induced liver injury in rats. Arch Toxicol 84: 389-396.

55. Gupta SC, Patchva S, Aggarwal BB (2013) Therapeutic roles of Curcumin: Lessons Learned from Clinical Trials. AAPS J 15: 195-218.

56. Fakoy A, Olusola AO (2019) Free Radicals Scavenging Potential of Buccholzia coriacea Extract and Ameliorative Effect in ParacetamolInduced Nephrotoxicity and Hepatotoxicity in Rats. International Journal of Research in Pharmacy and Biosciences 6: 1-11.

57. Ichimura T, Bonventre JV, Bailly V, Wei H, Hession CA, et al. (1998) Kidney injury molecule-1 (KIM-1), a putative epithelial cell adhesion molecule containing a novel immunoglobulin domain, is upregulated in renal cells after injury. J Biol Chem 273: 4135-4142.

58. McKay GA, Walters MR (2013) Clinical Pharmacology and Therapeutics. $9^{\text {th }}$ Edition, Hoboken, Wiley. 453: 221-234.

59. Dimari J, Meggyesi J, Udvarhelyei N, Price P, Davis R, et al. (1997) $\mathrm{N}$-acetylcysteine ameliorates ischemic renal failure. Am J Physiol 272: 292-298.

60. Ancha HR, Kurella RR, McKimmey CC, Lightfoot S, Harty RF (2009) Effects of $\mathrm{N}$-acetylcysteine plus mesalamine on prostaglandin synthesis and nitric oxide generation in TNBS-induced colitis in rats. Dig Dis Sci 54: 758-766.

61. Xing C-Y, Saleem MA, Coward RJ, Ni L, Witherden IR, et al. (2016) Direct effects of dexamethasone on human podocytes. Kidney Int 70: 1038-1045.

62. Ibiam, Ama U, Ugo AE, Orji, Uch O, et al. (2018) Anti-Inflammatory Effects of Buchholzia Coriacea Ethanol Leaf-Extract and Fractions in Freund's Adjuvant-Induced Rheumatoid Arthritis Albino Rats. IAJPS 05: 6341-6357.

63. Mata M, Morcillo E, Gimeno C, Cortijo J (2011) N-acetyl-L-cysteine (NAC) inhibit mucin synthesis and pro-inflammatory mediators in alveolar type II epithelial cells infected with influenza virus A and B and with respiratory syncytial virus (RSV). Biochem Pharmacol 82: 548-555. 